\title{
Angiotensin-Converting Enzyme Inhibitor-Induced Non-allergic Perioral Angioedema: A Case-Based Scoping Review
}

\author{
Poramate Pitak-Arnnop ${ }^{1, *}$, Keskanya Subbalekha ${ }^{2}$, Chayawee Muangchan ${ }^{3}$, Prim Auychai ${ }^{4}$, Nattapong Sirintawat ${ }^{5}$, \\ Jean-Paul Meningaud ${ }^{6}$, Andreas Neff ${ }^{1}$
}

'Department of Oral and Maxillofacial Surgery, University Hospital of Giessen and Marburg, UKGM GmbH, Campus Marburg, Faculty of Medicine, Philipps-University of Marburg, Marburg, Germany

${ }^{2}$ Department of Oral and Maxillofacial Surgery, Faculty of Dentistry, Chulalongkorn University, Bangkok, Thailand

${ }^{3}$ Division of Rheumatology, Department of Internal Medicine, Faculty of Medicine Siriraj Hospital, Mahidol University, Bangkok, Thailand

${ }^{4}$ Department of Pediatric Dentistry, Faculty of Dentistry, Chulalongkorn University, Bangkok, Thailand

${ }^{5}$ Department of Oral and Maxillofacial Surgery, Faculty of Dentistry, Mahidol University, Bangkok, Thailand

${ }^{6}$ Department of Plastic, Reconstructive, Aesthetic and Maxillofacial Surgery, Henri Mondor University Hospital, AP-HP, Faculty of Medicine, University Paris-Est Créteil Val de Marne (Paris XII), Créteil, France

Patients with angiotensin-converting enzyme inhibitor (ACEI)-induced angioedema (ACEIIA) may visit family physicians. The aim of this article was to describe a case of delayed-onset ACEIIA and to present a concise scoping review. Using a case report and a scoping review study design, we report a case of ACEIIA, with clinically confirmed diagnosis. The symptoms resolved after replacing the offending ACEI with another antihypertensive agent. After excluding other causes of perioral swelling and discontinuation of ACEI, the patient was symptom-free within a few days thereafter. Based on this case presentation, we performed a meta-narrative scoping review including up-todate diagnosis and management of ACEIIA, based on published data in English, French, and German from inception to April 1, 2021. Patients with angioedema of unknown origin should be cautiously examined to rule out oral diseases, including allergy to dental materials and drug-induced angioedema. Clinicopathological aspects and current treatment guidelines for ACEI-associated angioedema are also presented.

Keywords: Angioedema; Angiotensin-Converting Enzyme Inhibitors; Oral Medicine; Review

Received: April 30, 2021, Accepted: May 10, 2021

${ }^{*}$ Corresponding Author: Poramate Pitak-Arnnop https://orcid.org/0000-0002-7427-3461

Tel: +49-6421-58-63239, Fax: +49-6421-68990, E-mail: poramate.pitakarnnop@gmail.com 


\section{INTRODUCTION}

Perioral swelling can arise due to various diseases, and patients with unknown swelling in the orofacial region may visit family physicians for examination and proper management. In this concise article, we report a case of delayed-onset drug-induced angioedema, which was initially misdiagnosed, and provide a scoping review on diagnostic and therapeutic approaches to this disease, based on published data in English, French, and German until April 1, 2021. To the best of our knowledge, this study is the first to present evidence-based diagnostic and therapeutic protocols for drug-induced angioedema.

\section{CASE PRESENTATION}

The patient gave written consent for publication of his clinical data and image.

\section{Initial Presentation}

A 75-year-old Caucasian man presented with a 6-month fluctuation in painless perioral swelling, which did not respond to a course of antihistamine medications prescribed by his dermatologist.

\section{Relevant History}

The patient suffered from type 2 diabetes mellitus, chronic myeloid leukemia, hypertension, and hyperlipidemia and had undergone cholecystectomy and three sets of gastroduodenoscopy and colonoscopy. There was no history of fever or other constitutional symptoms. Aller-



Figure 1. Clinical picture of the patient. The patient gave written consent for publication of his clinical data and image.

Table 1. Classification of angioedema, ${ }^{2,8,12)}$

\begin{tabular}{|c|c|c|c|c|}
\hline Generic & Disease & Pathogenesis & Prevalence & Features \\
\hline \multirow[t]{3}{*}{$\begin{array}{l}\text { Mast-cell mediated } \\
\text { (allergic angioedema) }\end{array}$} & Anaphylaxis & IgE-mediated & Common & $\begin{array}{l}\text { Urticaria/pruritis; exposure to allergen (food, insects, } \\
\text { drugs, etc.); multisystem organ involvement }\end{array}$ \\
\hline & Allergic reaction & IgE-mediated & Common & $\begin{array}{l}\text { Preceded by exposure to allergen; rapid onset of } \\
\text { symptoms }\end{array}$ \\
\hline & Drug-induced & $\begin{array}{l}\text { IgE-mediated, enhanced by } \\
\text { prostaglandin formation }\end{array}$ & Common & $\begin{array}{l}\text { Exposure to aspirin or NSAIDs (except COX-2 } \\
\text { inhibitors); angioedema and bronchoconstriction }\end{array}$ \\
\hline \multirow[t]{6}{*}{$\begin{array}{l}\text { Bradykinin-mediated } \\
\text { (non-allergic angioedema) }\end{array}$} & ACEIS (DINAAE) & $\begin{array}{l}\text { Accumulation of bradykinin due to } \\
\text { overproduction or impaired } \\
\text { bradykinin degradation }\end{array}$ & Common & $\begin{array}{l}\text { ACEls (or ARB) therapy; higher incidence in African- } \\
\text { Americans: acute or delayed onset of symptoms }\end{array}$ \\
\hline & HAE type I (deficient C1-INH) & $\begin{array}{l}\text { Mutations in C1-INH gene } \\
\text { (SERPING1 gene) on chromosome } \\
11 \mathrm{q}\end{array}$ & Rare & $\begin{array}{l}\text { Begin in childhood and worsen during puberty; } \\
\text { autosomal-dominant inheritance; severe edema } \\
\text { with respiratory distress and abdominal pain }\end{array}$ \\
\hline & $\begin{array}{l}\text { HAE type II (dysfunctional } \\
\text { C1-INH) }\end{array}$ & Normal C1-INH level with dysfunction & Rare & Similar to HAE type I \\
\hline & HAE type III (normal C1-INH) & $\begin{array}{l}\text { Mutation in gene encoding } \\
\text { coagulation factor XII, which } \\
\text { cleaves prekallikrein to kallikrein }\end{array}$ & Rare & $\begin{array}{l}\text { Autosomal-dominant inheritance with low } \\
\text { penetrance; primarily affects women (estrogen } \\
\text { use-estrogen exacerbates the gene mutation); } \\
\text { delayed onset; face and tongue swelling }\end{array}$ \\
\hline & $\begin{array}{l}\text { Acquired C1-INH deficiency } \\
\text { type I }\end{array}$ & $\begin{array}{l}\text { C1-INH degraded by immune } \\
\text { complexes }\end{array}$ & Rare & $\begin{array}{l}\text { Age }>40 \text { years; angioedema without urticaria; } \\
\text { prodrome of erythema marginatum: underlying B } \\
\text { cell lymphoproliferative/lymphoreticular diseases }\end{array}$ \\
\hline & $\begin{array}{l}\text { Acquired C1-INH deficiency } \\
\text { type II }\end{array}$ & Anti-C1-INH-autoantibodies & Rare & Almost similar to acquired C1-INH deficiency type I \\
\hline \multirow[t]{2}{*}{$\begin{array}{l}\text { Unknown cause; bradykinin- } \\
\text { or histamine-mediated }\end{array}$} & $\begin{array}{l}\text { Chronic idiopathic } \\
\text { angioedema/chronic } \\
\text { urticaria }\end{array}$ & Unknown cause & Rare & $\begin{array}{l}>3 \text { angioedema attacks with urticaria in } 1 \text { year; } \\
\text { indeterminate cause; diagnose after exclusion of } \\
\text { other types }\end{array}$ \\
\hline & Gleich's syndrome & Unknown cause & Rare & $\begin{array}{l}\text { Elevated serum eosinophil and lgM levels; } \\
\text { cutaneous angioedema with/without urticaria; } \\
\text { history of treatment with calcium channel } \\
\text { blockers, rocuronium and propofol }\end{array}$ \\
\hline
\end{tabular}

IgE, Immunoglobulin E; NSAIDs, non-steroidal anti-inflammatory drugs; COX, cyclooxygenase; ACEls, angiotensin-converting enzyme inhibitors; DINAAE, drug-induced nonallergic angioedema; ARB, angiotensin receptor blocker; HAE, hereditary angioedema; C1-INH, C1 esterase inhibitor; IgM, Immunoglobulin M. 
gy, insect bites/stings, and familial history were also excluded.

\section{Relevant Physical Exam Findings}

Physical examination revealed firm, non-tender swelling of the lips and perioral region extending to the nasolabial folds (Figure 1), and clinically sound oral status, except for a partially edentulous area in the maxilla. There were no signs of intraoral swelling or airway obstruction.

\section{Relevant Diagnostics}

The patient's dermatologist suspected an allergy due to dental materials, that is, acrylic denture of the denture base. The blood chemical results were unremarkable. We decided to perform the allergy test in addition to suspicion of drug-induced non-allergic angioedema (DINAAE).

Patch testing, as described by Rai et al., ${ }^{1)}$ was performed using the Chemotechnique Dental Series of 30 materials commonly used in dentistry, including methyl methacrylate, a component of acrylicbased denture. The readings were recorded on days 2,3 , and 4 . There was no positive result, which was identified by the presence of erythema, papules, and vesicles, as recommended by the International Contact Dermatitis Research Group. ${ }^{1)}$ As a result, allergy to dental materials was excluded, and the suspected diagnosis was directed to DINAAE.

After reviewing his comorbidities, the patient took insulin aspart, insulin human/rDNA, linagliptin, imatinib, ondansetron, betahistine, epoetin alfa, ferrous fumarate, folic acid, desloratadine, enalapril, and fenofibrate. As angiotensin-converting enzyme inhibitors (ACEIs) and non-steroidal anti-inflammatory drugs are a common cause of DINAAE, revision of the antihypertensive agent has been suggested.

\section{Case Progression}

The patient's cardiologist replaced enalapril with candesartan, although the patient had received enalapril for over a decade. A few days

Table 2. Risk factors of ACEls-induced angioedema ${ }^{4,6,7,76-19)}$

\begin{tabular}{lll}
\hline \multicolumn{1}{c}{ Eenetic factors } & \multicolumn{1}{c}{ Environmental factors } & Genetic/environmental factors \\
\hline Black or Hispanic race & Trauma (facial impairment, dental surgery, anesthesia, intubation, transplantation, & Age $>65$ years \\
C1-INH deficiency & cardiac catherization) & History of cough due to ACEls \\
Female gender & Smoking & History of drug rash \\
& Aspirin and NSAIDs & Seasonal allergies \\
Immunosuppressive agents & Food/contact allergies \\
& Lidocaine & \\
DPP-IV inhibitors, e.g., saxagliptin & Neprilysin inhibitors, e.g., sacubitril & \\
& Estrogen & \\
mTOR inhibitors, e.g., sirolimus & Fibrinolytic
\end{tabular}

ACEls, angiotensin-converting enzyme inhibitors; C1-INH, C1 esterase inhibitor; NSAIDs, non-steroidal anti-inflammatory drugs; DPP-IV, dipeptidyl peptidase IV.



Figure 2. Mechanism of histamine- versus bradykinin-mediated angioedema. $2,8-10,22,23)$ TXA, tranexamic acid; HMWK, high-molecularweight kininogen; C1-INH, C1 esterase inhibitor; ACEls, angiotensin-converting enzyme inhibitors; ACE, angiotensin-converting enzyme; NEP, neutral endopeptidase; APP, aminopeptidase; DPP-IV, dipeptidyl peptidase IV; $\downarrow$, activation; $\perp$, inhibition. 
after stopping enalapril, the angioedema resolved. The diagnosis of DINAAE was clinically established with no attempt to perform further laboratory investigations, which were denied by the patient. Owing to mild-to-moderate symptoms and unclear practice guidelines in Germany at the time of diagnosis, no new targeted therapies were provided (targeted therapies are described below).

\section{Final Case Outcome}

At the time of this manuscript preparation, the patient has been off ACEI and symptom-free for 6 years since discontinuing enalapril.

\section{SEARCHING STRATEGY}

\section{Study Design and Samples}

Using a literature review design, we searched the PubMed/Medline (https://pubmed.ncbi.nlm.nih.gov/), Embase (https://www.embase. com), Biomed Central (https://www.biomedcentral.com/), and Cochrane Library (https://www.cochranelibrary.com/) from inception until April 1, 2021, to identify literature in English, French, and German. The search terms were "angioedema" AND "angiotensin-converting enzyme inhibitors." Only studies or reports on ACEI-related angioedema were included. No restrictions on the samples were applied. References of the selected papers were searched for relevant studies that were included in the analyses. As this was a scoping narrative review, no attempt was made to identify unpublished studies, literature in languages other than English, French, and German, to contact researchers for unpublished data, or to perform a meta-analysis.
The need for ethical approval was waived. However, the ethical guidelines of the World Medical Association's Declaration of Helsinki version 2008 (https://www.wma.net/wp-content/uploads/2018/07/ DoH-Oct2008.pdf) and the RAMESES I (Realist and Meta-narrative Evidence Syntheses: Evolving Standards) guidelines for meta-narrative reviews (http://www.ramesesproject.org) were followed throughout the study.

\section{Study Variables}

The primary outcome variables were the clinical, pathological, investigative, and therapeutic aspects of ACEI-associated angioedema.

\section{Data Collection and Analysis}

We reviewed each report and abstracted the data. Appropriate statistics were computed when indicated. The highest level of evidence after the Oxford Centre for Evidence-Based Medicine (https://www.cebm. ox.ac.uk/resources/levels-of-evidence/oxford-centre-for-evidencebased-medicine-levels-of- evidence-march-2009) was selected for the review.

\section{LITERATURE REVIEW, DISCUSSION AND TEACHING POINTS}

ACEIs were first introduced in 1981 for treatment of hypertension and heart failure, and later for myocardial infarction and stroke. ${ }^{2-4)}$ In Germany, this drug group is the most prescribed: approximately 54.8 million prescriptions a year. ${ }^{2,3)}$ Classical adverse reactions due to ACEIs

Table 3. Pathogenesis of drug-induced non-allergic angioedema9,24)

\begin{tabular}{|c|c|c|}
\hline Mechanism & Drugs* & Description \\
\hline Synthesis of bradykinin with C1-INH suppression & Risperidone & $\begin{array}{l}\text { Increased bradykinin production by inhibiting C1-INH but increasing } \\
\text { complement activity }\end{array}$ \\
\hline Synthesis of bradykinin with increased plasmin & $\mathrm{rtPA}^{\dagger}$ & $\begin{array}{l}\text { Increased bradykinin production by increasing plasmin and complement } \\
\text { activity }\end{array}$ \\
\hline Response to bradykinin at B2 receptors & Statins & $\begin{array}{l}\text { Increased } B R 2 \text { gene expression on endothelial cells and their sensitivity to } \\
\text { bradykinin }\end{array}$ \\
\hline $\begin{array}{l}\text { Metabolism of bradykinin and substance P with ACE } \\
\text { and DPP-IV suppression }\end{array}$ & $\begin{array}{l}\text { ACEls on ACE; sitagliptin and } \\
\text { vildagliptin on DPP-IV }{ }^{\ddagger}\end{array}$ & $\begin{array}{l}\text { Inhibit/inactivate substance P degradation. ACEI also decreases metabolism } \\
\text { of bradykinin }\end{array}$ \\
\hline
\end{tabular}

C1-INH, C1 esterase inhibitor; rtPA, recombinant tissue plasminogen; ACE, angiotensin-converting enzyme; DPP-IV, dipeptidyl peptidase IV; ACEls, angiotensin-converting enzyme inhibitors.

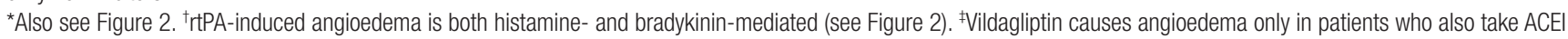
concomitantly.

Table 4. Laboratory investigations of different types of bradykinin-mediated angioedema ${ }^{12,22)}$

\begin{tabular}{|c|c|c|c|c|c|}
\hline \multirow{2}{*}{ Variable } & \multicolumn{3}{|c|}{ Decreased C1-INH } & \multicolumn{2}{|c|}{ Normal C1-INH } \\
\hline & HAE type I & HAE type II & Acquired C1-INH deficiency & HAE type III & ACEIS (DINAAE) \\
\hline C1-INH concentration & $<50 \%$ & Normal (or increased) & $<50 \%$ & Normal & Normal \\
\hline C1-INH function & $<50 \%$ & $<50 \%$ & $<30 \%$ & Normal & Normal \\
\hline C4 concentration & Normal (or decreased) & Normal (or decreased) & $<50 \%$ (70\% of cases) & Normal & Normal \\
\hline C4 function & $<50 \%$ & $<50 \%$ & $<50 \%$ & Normal & Normal \\
\hline Anti-C1-INH antibodies & Absent & Absent & Present (70\% of cases) & Absent & Absent \\
\hline Mutation & SERPING1 (95\% of cases) & SERPING1 (95\% of cases) & Absent & $F 12$ and $P L G$ & Absent \\
\hline
\end{tabular}

C1-INH, C1 esterase inhibitor; HAE, hereditary angioedema; ACEls, angiotensin-converting enzyme inhibitors; DINAAE, drug-induced non-allergic angioedema. 
include dry/nonproductive cough (5.3\%), angioedema ("Quincke's edema”, $0.1 \%-0.7 \%)$, hyperkalemia ( $0.4 \%)$, and bronchospasm/wheez$\operatorname{ing}(0.3 \%){ }^{2,4-7)}$

Angioedema manifests as sudden localized, non-pitting swelling of certain body parts including skin and mucosa. ${ }^{7-10)}$ It is important to segregate allergic, histamine-mediated angioedema from its non-allergic, often bradykinin-mediated counterparts. ${ }^{2)}$ The latter form of angioedema lacks pruritus, urticaria, hypotension, tachycardia, or increased airway pressure because of no mast-cell involvement. ${ }^{5,8,10-12)}$

Hereditary angioedema (HAE) due to $\mathrm{Cl}$ esterase inhibitor (C1-INH) deficiency is a rare autosomal dominant disease (ORPHA:91378), with a prevalence of 1:50,000. It arises from a mutation in the SERPING1 gene, which encodes C1-INH. ${ }^{13,14)}$ Recurrent DINAAE is another form of non-histaminergic angioedema. African-Americans are at higher risk of DINAAE, probably due to the C-2399A genetic polymorphism of the bradykinin-degrading enzyme aminopeptidase (encoded by the $\mathrm{X}$-linked XPNPEP2 gene)., ${ }^{7,810,15,16)}$ Stress, anxiety, menstruation, anesthetic agents (e.g., disoprivan, remifentanyl), immunosuppressants, Helicobacter pylori infection, and smoking can precipitate an exacerbation of DINAAE, ${ }^{2,4,12)}$ while diabetes and obesity seem to be protective factors against the disease severity. ${ }^{6,7)}$ A recent study unveiled the histomorphological differences between angioedema from C1-INH deficiency and DINAAE due to ACEIs; only the former had structural capillary alterations, that is increased intercapillary distance, apical, internal and external diameters, irregular capillary distribution, and tortuous morphology, as well as decreased microvascular density. These morphological changes confirm endothelial dysfunction in angioedema from C1-INH deficiency, but not ACEIs-induced angioedema. ${ }^{14)}$ Table 1 summarizes the classification of angioedemas, ${ }^{2,8,12)}$ and Table 2 concludes risk factors of DINAAE due to ACEIs., ${ }^{4,6,7,16-19)}$

Although angioedema has many subtypes, the core pathogenesis is a temporary increase in endothelial permeability of postcapillary veins, which in turn leads to plasma extravasation in the deeper layers of the dermis and submucosa. While facial and genital skin is mostly affected, the extremities, airways, and intestinal tract may also be involved. Laryngeal symptoms vary from mild edema to severe respiratory distress and asphyxiation. Intestinal tract angioedema may present as abdominal pain with/without nausea, vomiting, diarrhea, and ascites, which may be confused with a surgical abdomen, and may even result in psychiatric referrals. . $^{4,8,12,16-18,20)}$

Bradykinin is a local inflammatory mediator that activates bradykinin beta-2 adrenergic (B2) receptors, resulting in the release of nitric oxide and prostacyclin. Both mediators elicit vasodilation and increased vascular permeability and cause smooth muscle cells to contract via pathways involving vascular endothelial cadherin, endothelial nitric oxide synthase, and vascular endothelial growth factor-A. Angiotensin-converting enzyme (ACE), neutral endopeptidase (NEP), aminopeptidase P, DPP-IV (dipeptidyl peptidase IV), and kininase I degrade bradykinin and substance $\mathrm{P}$, and synthesize angiotensin II from angiotensin I in the renin-angiotensin-aldosterone system. Inhibition of bradykinin degradation by ACEIs enhances the half-life of bradykinin and results in plasma extravasation into submucosal/subcutaneous tissue. Substance P also increases vascular permeability through its action on NK1 receptors. Moreover, DINAAE due to ACEIs is also linked to an impairment of cytokine degradation with an increase in the level of C-reactive protein (Figure 2).,2,6,8-10,12-14,16,21-23) This adverse reaction is medication-specific, but not dependent upon dosage. ${ }^{2,5)}$ The different pathogenesis of DINAAE are presented in Table $3 .{ }^{9,24)}$ DINAAE due to drugs other than ACEIs may occur in patients with and without ACEI therapy. ${ }^{10)}$

Until now, no useful diagnostic test for DINAAE from ACEIs is available. The diagnostic criteria can therefore be established using history

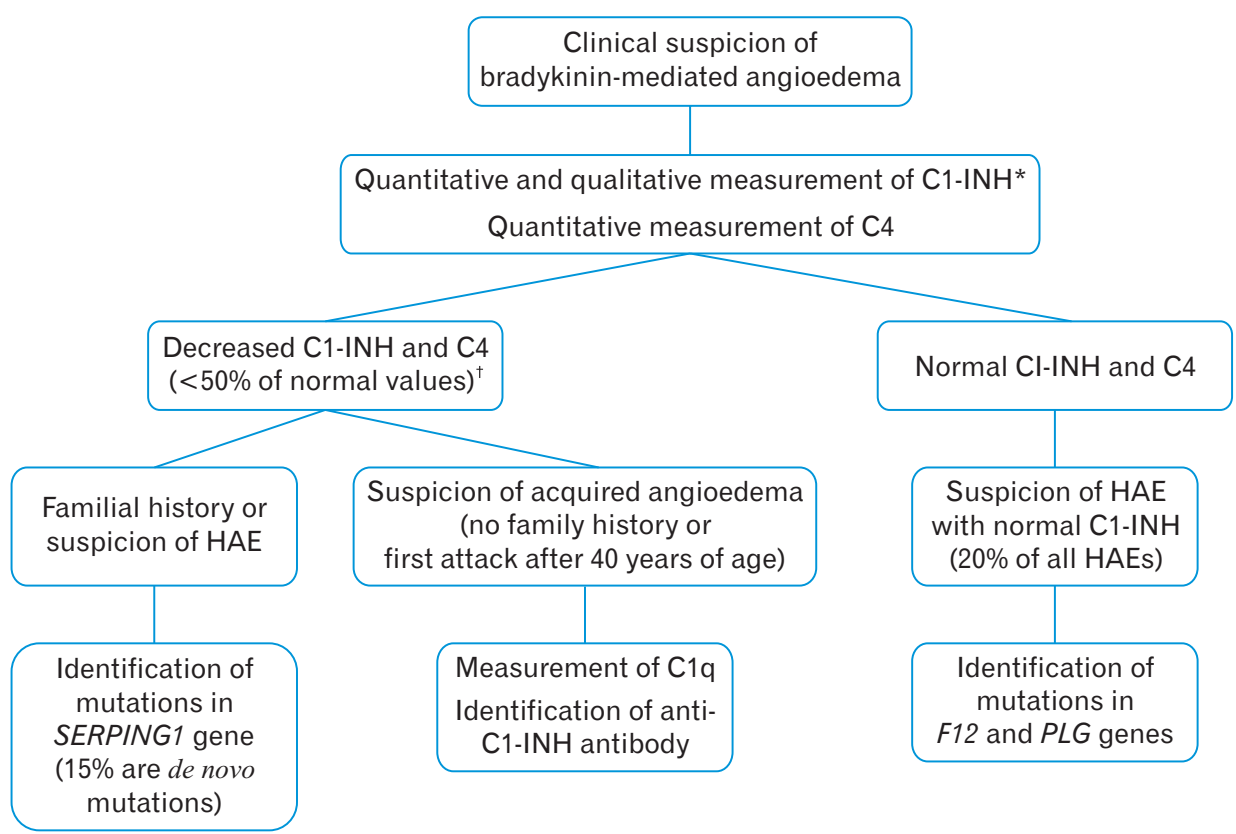

Figure 3. The 2019 French guideline on laboratory investigation of bradykininmediated angioedema according to the French National Centre of Reference for Angioedema ("Centre de Référence National des Angiœdèmes"; CREAK). ${ }^{22}$ HAE, hereditary angioedema. ${ }^{*} \mathrm{C} 1$ esterase inhibitor (C1-INH) measurement in patients on $\mathrm{C} 1-\mathrm{INH}$ or danazol therapy requires "drug-pause" interval 1 and 4 weeks before the test, respectively. 'The test should be repeated, if the result shows $50 \%-60 \%$ of normal values. 
taking concerning ACEI therapy, regardless of dose/duration of use, non-specific angioedema, resolution of symptoms after stopping the ACEI and lack of another diagnosis. ${ }^{4,17,18)}$ Most DINAAEs are mild and resolve within 48-72 hours after discontinuing the offending ACEIs. ${ }^{6,7)}$ Clinically, approximately $1 / 3$ of the cases present with swelling of lips, tongue, and face, and probably, tongue, pharynx and larynx, which may cause life-threatening upper airway obstruction., ${ }^{2,71,21)}$ It is therefore recommended to admit DINAAE patients with airway involvement in an intensive care unit for at least 12-24 hours, and artificial airway (intubation, cricothyrotomy, tracheostomy) may be necessary. ${ }^{2,11)}$ Chiu et al. ${ }^{25)}$ classified angioedema into three classes to predict airway risks: class 1 involves the face and oral cavity only, class 2 extends to the oral floor and oropharynx, and class 3 invades glottis and supraglottis. Class 2 and 3 angioedema require endotracheal intubation and hospitalization for a minimum of 12-24 hours of observation. Rapid progression of symptoms within the first 6 hours of angioedema onset, anterior tongue swelling, vocal changes, drooling, and dyspnea are common signs of severe airway obstruction. ${ }^{26)}$

After an acute angioedema attack, C4 levels should be investigated for the diagnosis of HAE, and testing tryptase levels aids in the diagnosis of allergic angioedema. Low $\mathrm{C} 4$ is associated with HAE and is therefore a good screening test for C1-INH deficiency. Tryptase is normal in HAE but may be elevated in mast-cell disorders or other causes of anaphylaxis manifesting as angioedema. ${ }^{8)}$ Recently, the French National Centre of Reference for Angioedema ("Centre de Référence National des Angiœdèmes"; CREAK) issued the guideline on laboratory investigation of bradykinin-mediated angioedema (Table 4, Figure 3). ${ }^{12,22)} \mathrm{C} 1-\mathrm{INH}$ and $\mathrm{C} 4$ testing should be performed thrice within an appropriate interval, that is, $2-4$ weeks. ${ }^{22)}$

Family physicians, emergency physicians, otolaryngologists, dermatologists, and dentists should be familiar with DINAAE. In Germany, all cases with DINAAE must be reported to the German's Federal Institute for Drugs and Medical Devices ("Bundesinstitut für Arzneimittel und Medizinprodukte": BfArM). ${ }^{2)}$ With the average rate of ACEIs-in-

Table 5. US Food and Drug Administration-approved targeted therapies/prophylaxis for acute attacks of bradykinin-mediated, non-allergic angioedema ${ }^{2,8,11,12)}$

\begin{tabular}{|c|c|c|c|c|c|}
\hline $\begin{array}{l}\text { Generic } \\
\text { name }\end{array}$ & $\begin{array}{l}\text { Brand name } \\
\text { (manufacturer) }\end{array}$ & Description & Dose & Side effects & Remarks \\
\hline Icatibant & $\begin{array}{l}\text { Firazyr (Shire, Lexington, } \\
\text { MA, USA; approved in } \\
\text { 2011) }\end{array}$ & $\begin{array}{l}\text { Synthetic bradykinin B2 } \\
\text { receptor antagonist, } \\
\text { which displaces } \\
\text { bradykinin from B2 } \\
\text { receptors }\end{array}$ & $\begin{array}{l}30 \text { mg s.c., repeat } \\
\text { after 6-8 hours if } \\
\text { symptoms persist } \\
\text { (maximum } \\
3 \text { times/d) }\end{array}$ & $\begin{array}{l}\text { Rash, headache, nausea, local } \\
\text { irritation at the injection site, fever, } \\
\text { fatigue, asthenia, dizziness }\end{array}$ & $\begin{array}{l}\text { Only for HAE patients } \geq 18 \text { years of } \\
\text { age; off-labelled use for DINAAE; } \\
\text { administration by healthcare } \\
\text { professionals only; no } \\
\text { accumulation following multiple } \\
\text { doses }\end{array}$ \\
\hline Ecallantide & $\begin{array}{l}\text { Kalbitor (Shire, Lexington, } \\
\text { MA, USA; approved in } \\
\text { 2009) }\end{array}$ & $\begin{array}{l}\text { Potent and selective } \\
\text { human plasma kallikrein } \\
\text { inhibitor }\end{array}$ & 10 mg s.c. 3 times/d & $\begin{array}{l}\text { Similar to icatibant; anaphylactoid- } \\
\text { type reactions (3\%); prolonged } \\
\text { aPTT (precaution when used } \\
\text { together with aspirin, heparin or } \\
\text { other anticoagulants) }\end{array}$ & $\begin{array}{l}\text { Only for HAE patients } \geq 12 \text { years of } \\
\text { age; off-labelled use for DINAAE; } \\
\text { administration by healthcare } \\
\text { professionals only }\end{array}$ \\
\hline \multirow[t]{4}{*}{$\mathrm{C} 1-\mathrm{INH}$} & $\begin{array}{l}\text { Berinert (CSL Behring, King } \\
\text { of Prussia PA, USA; } \\
\text { approved in 2011) }\end{array}$ & $\begin{array}{l}\text { Human plasma-derived } \\
\text { C1-INH, which inhibits } \\
\text { several targets (activated } \\
\text { C1s, kallikrein, factor } \\
\text { Xlla, factor Xia, thrombin, } \\
\text { tPA and plasmin) }\end{array}$ & 20 IU/kg i.v. & $\begin{array}{l}\text { Dysgeusia (>4\%), headache, nausea, } \\
\text { rash, vomiting, risk of blood-borne } \\
\text { infections, risk of thromboembolism } \\
\text { in patients with risk factors } \\
\text { (indwelling venous catheter/access } \\
\text { device, prior history of thrombosis, } \\
\text { underlying atherosclerosis, use of } \\
\text { estrogen/androgen, morbid obesity } \\
\text { and immobility) }\end{array}$ & $\begin{array}{l}\text { For treatment of acute HAE attacks } \\
\text { involving facial, abdominal, or } \\
\text { laryngeal regions in adults and } \\
\text { adolescents; use as prophylaxis } \\
\text { within } 6 \text { post-procedure hours (at } \\
\text { a dose of } 1,000 \text { IU); administration } \\
\text { by healthcare professionals only }\end{array}$ \\
\hline & $\begin{array}{l}\text { Cinryze (Shire, Lexington, } \\
\text { MA, USA; approved in } \\
\text { 2008) }\end{array}$ & Similar to Berinert & $\begin{array}{l}\text { 1,000 IU i.v. every } \\
3-4 \text { days }\end{array}$ & $\begin{array}{l}\text { Similar to Berinert, risk of } \\
\text { thromboembolism in case of long- } \\
\text { term HAE prophylaxis }\end{array}$ & $\begin{array}{l}\text { Self-administration as prophylaxis of } \\
\text { HAE attacks in adolescence and } \\
\text { adults }\end{array}$ \\
\hline & $\begin{array}{l}\text { Haegarda (CSL Behring, } \\
\text { King of Prussia PA, USA; } \\
\text { approved in 2017) }\end{array}$ & Similar to Berinert & $\begin{array}{l}20 \mathrm{lU} / \mathrm{kg} \text { s.c. every } \\
3-4 \text { days }\end{array}$ & $\begin{array}{l}\text { Injection site reaction, } \\
\text { hypersensitivity, nasopharyngitis, } \\
\text { dizziness }\end{array}$ & $\begin{array}{l}\text { Self-administration as prophylaxis of } \\
\text { HAE attacks in adolescence and } \\
\text { adults }\end{array}$ \\
\hline & $\begin{array}{l}\text { Ruconest (Salix, Raleigh, } \\
\text { NC, USA; approved in } \\
\text { 2014) }\end{array}$ & $\begin{array}{l}\text { Recombinant C1-INH, } \\
\text { purified from raw milk of } \\
\text { transgenic rabbits }\end{array}$ & $\begin{array}{l}<84 \mathrm{~kg}: 50 \mathrm{IU} / \mathrm{kg} \text { i.v. } \\
>84 \mathrm{~kg}: 4,200 \mathrm{IU} \\
\text { (2 vials) i.v. }\end{array}$ & $\begin{array}{l}\text { Headache, vertigo, diarrhea, risk of } \\
\text { thromboembolism similar to } \\
\text { Berinert }\end{array}$ & $\begin{array}{l}\text { For treatment of acute HAE attacks; } \\
\text { administration by healthcare } \\
\text { professionals only }\end{array}$ \\
\hline Danazol & $\begin{array}{l}\text { Danol (Sanofi, Berkshire, } \\
\text { UK; approved for } \\
\text { laryngeal angioedema in } \\
\text { 2012) }\end{array}$ & $\begin{array}{l}\text { Synthetic steroid with } \\
\text { antigonadotropic and } \\
\text { anti-estrogenic activities }\end{array}$ & $\begin{array}{l}200 \mathrm{mg} \text { p.o. 2-3 } \\
\text { times/d (increased } \\
\text { dose up to } 200 \\
\mathrm{mg} / \mathrm{d})^{*}\end{array}$ & $\begin{array}{l}\text { Androgen-like effects (weight gain, } \\
\text { acne, seborrhea, hirsutism, } \\
\text { hoarseness; in females, menstrual } \\
\text { disturbances, flushing, sweating, } \\
\text { vaginal dryness, decreased } \\
\text { estrogen), hepatic toxicity }\end{array}$ & $\begin{array}{l}\text { For treatment of endometriosis and } \\
\text { fibrocystic breast disease and for } \\
\text { prophylaxis of HAE attacks in } \\
\text { females and males }\end{array}$ \\
\hline
\end{tabular}

S.C., subcutaneously; HAE, hereditary angioedema; DINAAE, drug-induced non-allergic angioedema; aPTT, activated partial thromboplastin time; C1-INH, C1 esterase inhibitor; IU, international units; i.v., intravenously; p.o., oral doses.

${ }^{*}$ Dose for prophylaxis of HAE attacks. 
duced angioedema of $0.4 \%$ and approximately 7 -million ACEIs users, it can be expected that nearly 30,000 ACEIs-induced angioedema cases per year in this country should be diagnosed. ${ }^{2,10)}$ Enalapril prescription in Germany is approximately 5.5 million per year and causes angioedema in more than $10 \%$ of the patients, ${ }^{27)}$ compared to the international incidence rate of $0.7 \% .{ }^{16)}$ It is estimated that $10 \%-30 \%$ of angioedema patients attending emergency departments are DINAAE due to ACEIs. ${ }^{26)}$

The highest incidence of ACEI-induced DINAAE occurred during the first month after initiation of therapy (3.6 events per 1,000 patients), and before a sharp decline until weeks 9-12. After week 12 , the incidence is usually low and constant (0.3-0.6 events per 1,000 patients). ${ }^{16)}$ This may be a clear explanation why many patients tolerate the ACEIs well, so that angioedema may attack many months or years after the beginning of uneventful treatment, ${ }^{2,6,16,17)}$ as seen in our patient. Bas et al ${ }^{28)}$ found that DINAAE developed on average after taking ACEIs for 3 years. Latent DINAAE may attack even after discontinuation of ACEI. ${ }^{6,8,17)}$

Based on the recent European ADR database EudraVigilance of the European Medicine Agency, Dubrall et al. ${ }^{19)}$ found that ACEI-associated DINAAE tended to be life-threatening without urticaria and required prolonged hospitalization in comparison with DINAAE from angiotensin receptor blocker (ARB) sartans and aliskiren (renin inhibi- tor). Sartans are often used instead of ACEIs in patients developing ACEI-associated side effects. ${ }^{20}$ However, a large series $(n=14,703)$ reported by Pfeffer et al. ${ }^{29)}$ demonstrated no significant difference in the incidence of DINAAE between ACEIs and sartans. A recent pharmacogenomic study revealed an association between intronic-1 variants in the calcium-activated potassium channel subunit alpha-1 (KCNMA1) gene on chromosome 10 and both DINAAE from ACEIs and ARBs. Calcium-activated potassium channel genes are expressed in vascular smooth muscle and endothelium, and encode effector proteins essential for the control of vascular tone and blood pressure. $\mathrm{KC}$ NMA1 encodes the pore-forming alpha subunit of the large-conductance calcium-dependent potassium big K (BK) channel, which is important for repolarization of the cell membrane. Thus, it is reasonable to believe that the deficient transport of calcium and/or potassium across the cell membrane plays a role in the development of angioedema. ${ }^{15)}$ As this genetic alteration was found in both DINAAE from ACEIs and ARBs, close follow-up is also important even for patients with sartan therapy after quitting ACEIs.

There is no international standard treatment for DINAAE. Early evidence recommended infusion of fresh-frozen plasma in an acute setting because it provides C1-INH. However, the risks of transmission of blood-borne pathogens, fluid overload, and hypersensitivity reactions should be kept in mind. ${ }^{2,8,11,16)}$ Wang et al. ${ }^{23)}$ advised the addition of

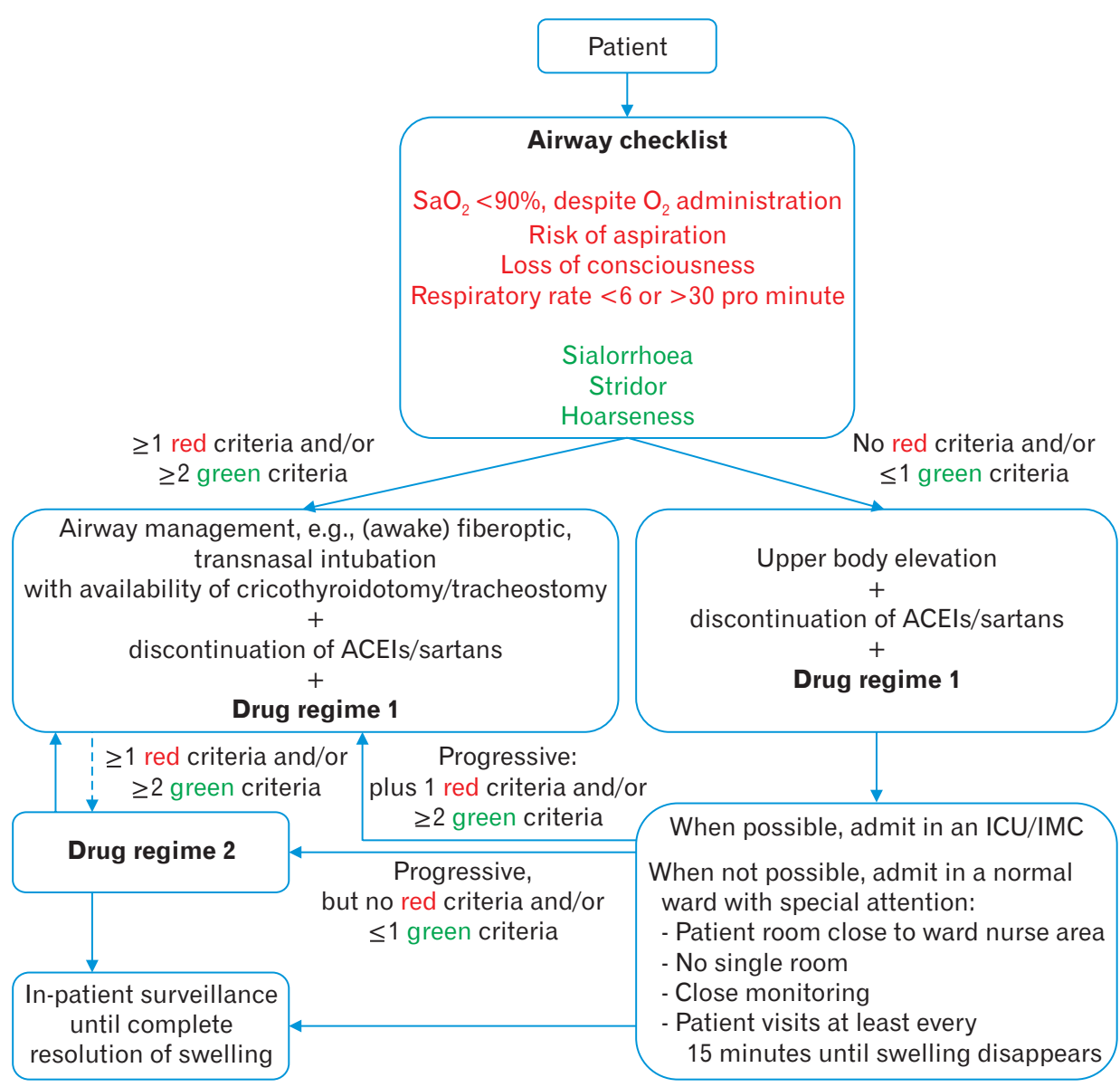

Figure 4. The 2019 emergency care algorithm for treatment of adult drug-induced non-allergic angioedema patients with acute airway compromise proposed by the University Hospital of Ulm, Germany. ${ }^{20)}$ Drug regime 1: Prednisolon 250-1,000 mg i.v. + dimetindene 4-8 mg i.v. + ranitidine $50 \mathrm{mg}$ i.v. + adrenaline $0.2-0.5 \mathrm{mg}$ i.m.; Drug regime 2: C1 esterase inhibitor (C1-INH) concentrate Berinert $20 \mathrm{IU} / \mathrm{kg}$ i.v. or Icatibant $30 \mathrm{mg}$ s.C. $\mathrm{SaO}_{2}$, oxygen saturation; ACEls, angiotensinconverting enzyme inhibitors; ICU, intensive care unit; IMC, intermediate medical care ward; i.v., intravenous; i.m., intramuscular; s.c., subcutaneous. 
tranexamic acid to epinephrine, corticosteroids, and H1- and H2blockers (Figure 2). Nevertheless, DINAAE often resists common therapies for histaminergic or anaphylactic etiologies, such as adrenaline, H-1 antagonists, and corticosteroids. Recently, the US Food and Drug Administration approved new, targeted therapies/prophylaxis for acute attacks of non-histaminergic angioedema (Table 5) ${ }^{2,8-12,16)}$ In 2019, an emergency care protocol for the treatment of DINAAE was developed at the University Hospital of Ulm, Germany (Figure 4). ${ }^{20)}$ Notwithstanding the positive treatment outcomes reported in the literature, it is noteworthy that all drugs used in this algorithm are still off-label.

\section{CONCLUSION}

Although most patients with recurrent orofacial swelling suffer from odontogenic infections, DINAAE should be considered in the differential diagnosis. When this angioedema type is suspected, the causal drug should be discontinued and substituted with other agents as soon as possible. Our patient was a typical case of delayed-onset DINAAE due to enalapril (reported incidence $0.7 \%$ ). ${ }^{16)}$ Emergency measures in a timely manner are required for patients with acute airway compromise, such as asphyxiation, stridor, retractions, and paradoxical chest movement. Targeted therapy for DINAAE remains off-label.

\section{CONFLICT OF INTEREST}

No potential conflict of interest relevant to this article was reported.

\section{ORCID}

Poramate Pitak-Arnnop: https://orcid.org/0000-0002-7427-3461

Keskanya Subbalekha: https://orcid.org/0000-0002-1570-2289

Chayawee Muangchan: https://orcid.org/0000-0002-5412-4055

Prim Auychai: https://orcid.org/0000-0002-6505-3424

Nattapong Sirintawat: https://orcid.org/0000-0002-6441-5243

Jean-Paul Meningaud: https://orcid.org/0000-0001-9227-9026

Andreas Neff: https://orcid.org/0000-0001-5865-0020

\section{REFERENCES}

1. Rai R, Dinakar D, Kurian SS, Bindoo YA. Investigation of contact allergy to dental materials by patch testing. Indian Dermatol Online J 2014;5:282-6.

2. Both C, Bas M, Wendland R, Kojda G. Nichtallergisches Angioödem: Nebenwirkung von ACE-Hemmern [Non-allergic angioedema: side effect of ACE inhibitors]. Pharmazeut Ztg [Internet] 2011;156:2890-4 [cited 2021 Apr 1]. Available from: https://www.pharmazeutische-zeitung.de/ausgabe-342011/nebenwirkung-von-ace-hemmern/.

3. Schwabe U. Arzneiverordnungen 2013 im Uberblick [Overview of drug prescriptions 2013]. In: Schwabe U, Paffrath D, editors. Arzneiverordnungs: report 2014 [Drug prescription: report 2014]. Berlin: Springer; 2014. p. 3-46.
4. Mihaela Leru P, Florin Anton V, Bocsan C, Muntean A, Boda D. Acquired angioedema induced by angiotensin-converting enzyme inhibitors: experience of a hospital-based allergy center. Exp Ther Med 2020;20:68-72.

5. Halling F. Das unsichtbare Angioodem [The invisible angioedema]. ZM Online [Internet]. 2015;19:72-4 [cited 2021 Apr 1]. Available from: https://www.zm-online.de/archiv/2015/19/zahnmedizin/das-unsichtbare-angiooedem/seite/alle/.

6. Davin L, Marechal P, Lancellotti P, Martinez C, Pierard L, Radermecker R. Angioedema: a rare and sometimes delayed side effect of angiotensin-converting enzyme inhibitors. Acta Cardiol 2019;74:277-81.

7. Montinaro V, Cicardi M. ACE inhibitor-mediated angioedema. Int Immunopharmacol 2020;78:106081.

8. Misra L, Khurmi N, Trentman TL. Angioedema: classification, management and emerging therapies for the perioperative physician. Indian J Anaesth 2016;60:534-41.

9. Kalambay J, Ghazanfar H, Martes Pena KA, Munshi RA, Zhang G, Patel JY. Pathogenesis of drug induced non-allergic angioedema: a review of unusual etiologies. Cureus 2017;9:e1598.

10. Sachs B, Meier T, Nothen MM, Stieber C, Stingl J. Drug-induced angioedema : focus on bradykinin. Hautarzt 2018;69:298-305.

11. Koeniger R. Akute Lippen- und Zungenschwellung mit Schluckbeschwerden: allergie? [Acute lip and tongue swelling with difficulty swallowing: allergy?]. Bayer Arztebl [Internet] 2012;67:149 [cited 2021 Apr 1]. Available from: http://www.bayerisches-aerzteblatt.de/fileadmin/aerzteblatt/ausgaben/2012/04/einzelpdf/BAB_4_2012_149.pdf.

12. Kanani A, Betschel SD, Warrington R. Urticaria and angioedema. Allergy Asthma Clin Immunol 2018;14(Suppl 2):59.

13. Bork K. Recurrent angioedema and the threat of asphyxiation. Dtsch Arztebl Int 2010;107:408-14.

14. Cesoni Marcelli A, Loffredo S, Petraroli A, Carucci L, Mormile I, Ferrara $\mathrm{AL}$, et al. Nailfold videocapillaroscopic findings in bradykinin-mediated angioedema. J Investig Allergol Clin Immunol 2020 Apr 17 [Epub]. https://doi.org/10.18176/jiaci.0524

15. Rasmussen ER, Hallberg P, Baranova EV, Eriksson N, Karawajczyk M, Johansson C, et al. Genome-wide association study of angioedema induced by angiotensin-converting enzyme inhibitor and angiotensin receptor blocker treatment. Pharmacogenomics J 2020;20:770-83.

16. Kostis WJ, Shetty M, Chowdhury YS, Kostis JB. ACE inhibitor-induced angioedema: a review. Curr Hypertens Rep 2018;20:55.

17. Krause AJ, Patel NB, Morgan J. An unusual presentation of ACE inhibitor-induced visceral angioedema. BMJ Case Rep 2019;12:e230865.

18. Parreira R, Amaral R, Amaral L, Eloi T, Leite MI, Medeiros A. ACE inhibitor-induced small bowel angioedema, mimicking an acute abdomen. J Surg Case Rep 2020;2020:rjaa348.

19. Dubrall D, Schmid M, Stingl JC, Sachs B. Angioedemas associated with renin- angiotensin system blocking drugs: comparative analysis of spontaneous adverse drug reaction reports. PLoS One 2020;15: e0230632.

20. Hahn J, Bock B, Muth CM, Pfaue A, Friedrich D, Hoffmann TK, et al. The ulm emergency algorithm for the acute treatment of drug-induced, bradykinin-mediated angioedema. Med Klin Intensivmed Notfmed 2019;114:708-16.

21. Ciancio SG. Medications' impact on oral health. J Am Dent Assoc 2004;135:1440-8. 
22. Bouillet L, Defendi F, Hardy G, Cesbron JY, Boccon-Gibod I, Deroux A, et al. [Diagnostic biologique des angioedemes bradykiniques : les recommandations du CREAK]. Presse Med 2019;48(1 Pt 1):55-62.

23. Wang K, Geiger H, McMahon A. Tranexamic acid for ACE inhibitor induced angioedema. Am J Emerg Med 2021;43:292.

24. Maertins M, Wold R, Swider M. Angioedema after administration of tPA for ischemic stroke: case report. Air Med J 2011;30:276-8.

25. Chiu AG, Krowiak EJ, Deeb ZE. Angioedema associated with angiotensin II receptor antagonists: challenging our knowledge of angioedema and its etiology. Laryngoscope 2001;111:1729-31.

26. Mudd PA, Hooker EA, Stolz U, Hart KW, Bernstein JA, Moellman JJ. Emergency department evaluation of patients with angiotensin converting enzyme inhibitor associated angioedema. Am J Emerg Med
2020;38:2596-601.

27. Halling F. Zahnarztlich relevante Neben- und Wechselwirkungen der meistverordneten Arzneimittel in Deutschland [Dentally relevant side effects and interactions of the most prescribed drugs in Germany]. Dtsch Zahnarztl Z [Internet] 2013;68:669-76 [cited 2021 Apr 1]. Available from: https://doi.org/10.3238/dzz.2013.0669-0676.

28. Bas M, Kojda G, Bier H, Hoffmann TK. ACE inhibitor-induced angioedema in the head and neck region: a matter of time? HNO 2004;52: 886-90.

29. Pfeffer MA, McMurray JJ, Velazquez EJ, Rouleau JL, Kober L, Maggioni AP, et al. Valsartan, captopril, or both in myocardial infarction complicated by heart failure, left ventricular dysfunction, or both. N Engl J Med 2003;349:1893-906. 